\title{
ETHICAL CLIMATE AND BEHAVIORAL INTEGRITY: A STUDY OF THE DETERMINANTS OF ETHICAL LEADERSHIP UNDER POLITICAL MENTORING
}

Waqas Baig ${ }^{1}$, Rizwan Qaiser Danish ${ }^{2 *}$, Muqqadas Rehman ${ }^{3}$, Muhammad Hasnain ${ }^{4}$, Hafiz Fawad Ali ${ }^{5}$

${ }^{1}$ Hailey College of Commerce, University of the Punjab, Lahore, Pakistan; ${ }^{2 * 3,4}$ Institute of Business Administration, University of the Punjab, Lahore, Pakistan; ${ }^{5}$ Department of Management Sciences, University of Okara, Pakistan. Email: ${ }^{1}$ waqasbaig33@yahoo.com, ${ }^{2 *}$ rqdanish@ibapu.edu.pk, ${ }^{3}$ muqqadasrehman@ibapu.edu.pk, ${ }^{4}$ hasnain5573019@gmail.com, ${ }^{5}$ fawadali94@ hotmail.com

Article History: Received on $11^{\text {th }}$ April 2021, Revised on $30^{\text {th }}$ April 2021, Published on $8^{\text {th }}$ May 2021

Abstract

Purpose of the study: Unethical behavior has been a source of incremental cost in corporations worldwide, and its consequences are detrimental to organizational health. In today's turbulent environment, the role of leadership becomes even more vital under uncertainties. This study investigates the impact of ethical climate and behavioral integrity on ethical leadership through political mentoring.

Methodology: The data were collected through a self-administered questionnaire distributed to the employees of various service sectors of health, education, banks, insurance companies, telecommunication, hotels, and transportation. The overall useable response rate was 85\% (450 in total). The data were analyzed through SPSS version 22 and ADANCO version 2.2.

Main Findings: The findings of the study are evidence of a strong association among behavioral integrity, ethical climate, political mentoring, and ethical leadership. We also found the mediating role of political mentoring between behavioral integrity and ethical leadership and between ethical climate and leadership.

Applications of the study: This study is significant for the managers of the service sector in developing the ethical climate. It gives an insight to the leaders that they should guide their subordinates about the environment appropriately.

It means that the leader's role matters in building the organizational employees' character and success.

Novelty/Originality of the study: In this study, the role of political mentoring in ethical climate has been recognized, which contributes to business ethics. Furthermore, it bridges the literature gap related to the mediating role of political mentoring in an organizational climate.

Keywords: Political Mentoring, Ethical Climate, Ethical Leadership, Behavioral Integrity, Social Learning Theory.

\section{INTRODUCTION}

In this turbulent and contemporary business environment, a leader's behavior is considered ethical based on transparency, integrity, and authenticity (Saha et al., 2020). The concept of ethical leadership can be traced from previous researchers such as Loftus et al. (1978); Avolio and Gardner (2005). Ethical leadership can be explained as an independent concept with two dimensions: a moral manager and a moral person (Danish et al., 2021). The moral person shows the leader's attributes, whereas the moral manager represents the efforts made by the leader to promote ethical behavior (Wang et al., 2017). Ethical leadership is considered the influential element for any business organization (Zaim et al., 2020). A moral person perceives ethical leadership as the right behavior, moral trait, and good decision-making. In contrast, a moral manager allocates these ethical characteristics to subordinates by using discipline and reward, role modeling, and communication (Trevino et al. 2000).

The theoretical concept of social learning theory helps to explain ethical leadership within the organization (Danish et al., 2021). It can be interpreted as the way the ethical leaders guide the behavior of their employees at job place (Mo \& Shi, 2017). Bandura (1986); Charles (2016) defined social learning theory as the individuals learn from the punishments, rewards and also learn from others through imitation, modeling, and observation. It further explains that individuals pay attention to follow the behavior of attractive and credible role models. Leaders are considered legitimate normative role models. Employees in organizations are directly influenced by their leaders because they have the power to implement rewards and punishment. In this context, the social learning theory allows the individuals to learn from their surroundings because most of the pressures are built up through their interactions with other individuals (Bandura, 1986).

Simha and Cullen (2012) explained that an organizational ethical climate stimulates the individual viewpoint towards work involvement and behavior that escalates the organizational performance. Furthermore, Victor and Cullen (1988) mentioned that ethical climate depends on employees' perceptions of procedures and policies in the organization that enhance ethical conduct and improve employees' attitudes and behavior (Elci \& Alpkan, 2009). Ethical climate indicates the positive effect 
on the employee's ethical leadership behavior, job performance, and organizational commitment. Ethical climate impacts the ethical issues and decision-making processes with the moral criteria the individuals apply to resolve and grasp this issue. Therefore, employees consider that an ethical climate is necessary to maintain ethical leadership and develop harmony in the organizational procedures then the organization progresses.

Palanski and Yammarino (2007) first described integrity, who used this concept in various research articles in different ways. For instance, they explained that behavioral integrity is virtuous behavior and a parsimonious construct. Simons et al. (2007) defined the word integrity as the consistency between actions and words. Victor and Cullen (1988) defined the ethical climate as employees' shared perception of ethical procedures and practices of firms. Previous research showed the association of ethical climate with job satisfaction, turnover intentions, extra-role, and in-role behavior, commitment, and ethical behavior. Thus, the ethical climate provides meaningful insight into how it affects the employees and their attitude and behavior in the organization.

Burlew (1991) defined mentoring as it is a procedure where an expert person (mentor) provides guidelines, opportunities, and knowledge to the least experienced protégé (Haring, 1999, Danish et al., 2021). Incorporations and companies use mentoring for the sake of influential corporate culture, values, and expectations (Wilson \& Elman, 1990). There are three mentoring models: networking mentoring, grooming mentoring and blending mentoring. Networking mentoring involves more than two persons, and it is non-hierarchical. The second one is the grooming mentoring that involves the relationship of a more skilled mentor and less skilled protégé, and it is traditional (Kochan et al., 2015). Blending mentoring is the combination of networking and grooming mentoring (Haring, 1999). Silvester and Menges (2011) discussed formal and informal mentoring. In an organization, political informal mentoring is used because it is necessary for the smooth running of business operations.

\section{The rationale of the study}

This study aims to demonstrate whether political mentoring mediates the association between an organizational ethical climate and ethical leadership. Furthermore, it seeks to add up in the literature about the concept of political mentoring. It is a newly emerging term because a few mentoring studies were found in the literature but not in the context of the organizational environment. This study also determines whether behavioral integrity and political climate are directly related to ethical leadership. Finally, this study will be an effort to cover the overall service sector in the organizational environment.

\section{LITERATURE REVIEW AND HYPOTHESES DEVELOPMENT}

The theoretical framework and hypotheses of the study based on different theories are mentioned below:

\section{Relationship between Political Mentoring and Ethical Leadership}

The concept of leadership and mentoring is studied by Blass and Ferris (2007). They pointed out as "military provides a unique opportunity..., because the military develops $100 \%$ of its leadership from within..., the military develops its leaders throughout for a career." There are some beneficial military characteristics such as (1) global vision, (2) outside information of the world to enhance performance, (3) use networks to gain useful contacts. (4) have an optimistic approach to the organizational objectives and goals, (5) courage, competency, integrity, and commitment (Van-Gils et al., 2015). The functional approach of an effective leader and the mentors have many things in common. For example, a mentor must have a clear visualization of the latest things globally, such as the leader having a clear vision, and he enlists others about his vision. Both are visionaries and can take the individual and organization to a better place in the future.

Kouzes and Posner (2017) defined four basic behaviors that motivate the leader to get successful results. These are: (1) inspiring the shared vision, (2) enabling others to act, (3) modeling the way, and (4) encouraging the heart. Both have collected these behaviors through questionnaires, case analyses, and surveys. Leaders are willing to create a challenging environment for the employees to contribute to their success (Kouzes \& Posner, 2017). Leaders can force people to do the work. They put their vision ahead and try to convenience the people to gain support. Moreover, it is necessary first to model the way to become a successful leader. Based on the above discussion, the following hypothesis is generated:

\section{H1: Political mentoring is positively related to ethical leadership.}

\section{Relationship between Behavioral Integrity and Ethical Leadership}

Behavioral integrity can be defined as the perceived criterion between the leader's deed and words (Prottas, 2013; Jones, 2019). Simons (2002) and Leroy et al. (2011) explained several viewpoints that demonstrate behavioral integrity. The most important viewpoint is that the leader should be a man of action and words. He should always preach what he does in his daily matters. A leader should be aware of the actual values of the people. He should be mindful of himself. If he lacks selfawareness, then he cannot perform his tasks properly. 
Ethical leadership can be validated and identified in four different ways (Miao et al., 2018). First, balanced processing is defined as the leader's behavior in which he analyzes the factual information before making a decision and is not afraid of followers' negative views (Van-Gils et al., 2015). Second, self-awareness represents behavior that shows leaders are conscious of preferences, aware of personal needs, motivation, and wants. Third, the inner moral view is defined as selfregulation, which discusses the internal moral values and standards. The last one is relational transparency, which shows the association between leader and follower. All these elements are explained by Kernis and Goldman (2006) as "the unobstructed operation of one's true, or core self in one's daily enterprise" (Lakey et al., 2008). Avolio and Gardner (2005) further added that a leader must cooperate with everyone in the organization (Leroy et al., 2015). The following hypothesis is postulated based on these logical arguments:

\section{H2: Behavioral integrity is positively associated with ethical leadership.}

\section{Relationship between Ethical Climate and Ethical Leadership}

Schminke et al. (2005) claimed that organizational leaders influence the organizational ethical work environment (Qin et al., 2018). They studied the association of ethical climate and leader's moral development. Their results verify this relationship. Engelbrecht et al. (2017) discussed the positive association between ethical climate and transformational leadership. Finally, Neubert (2019) found a positive association between ethical climate and ethical leadership.

Ethical leadership has two main parts: (1) moral manager (ethical standards, punishing, communicating, rewarding, and role modeling ethical behavior, (2) moral person (justice, integrity, trustworthiness, and concerns for others) (Beadle-Brown et al., 2015). Ethical leaders represent many favorable personal characteristics and create a role model for their employees to follow. Dickson et al. (2020) explained how much leaders are interested in developing the ethical climate for the organizational better performance. Leaders are responsible for setting the organizational ethical tone by implementing procedures, policies, and practices to implement ethical behavior and control misconduct. Kozlowski and Doherty (1989) narrated that leaders perform as interpretive filters of group members' policies and processes. In light of these practices and policies, leaders give their views about the perception of climate. In the light of the above arguments, the following hypothesis is formulated:

\section{H3: Ethical leadership is positively related to ethical climate.}

\section{The Mediating Role of Political Mentoring between Behavioral Integrity and Ethical Leadership}

Simons (2002) discussed behavioral integrity as an individual's promises that he commits to some other person to fulfil. In another way, it can also be expressed as the extent to which a leader's commitment to what he says and what he means. According to the communicated intentions and values, which are considered high in behavioral integrity, the leader behaves according to the communicated intentions and values (Simons, 2002). To consider a leader as high in behavioral integrity does not ensure that leader's shared values are either morally shared or better for the subordinates. When the leader delivers a high level of behavioral integrity, subordinates react according to that shared values. Palanski and Yammarino (2007) discussed the certainty of subordinates with respect to leader's behavior (Engelbrecht et al., 2017).

Blass and Ferris (2007) defined mentoring as an effective way of developing skills and transmitting knowledge and information. Mentoring enhances the mental capability of a person (Chong et al., 2020). However, another perspective of mentoring is considered a vehicle that develops and builds political skills and knowledge (Thatcher \& Perrewé, 2002). The desire of the protégé to choose such a type of mentor helps him to become successful in his goals and missions in life (Young \& Perrewé, 2000). As Feldman and Weitz (1991) wrote: "in choosing mentors, an ambitious protégé would be more interested in finding mentors who could open doors for them, sponsor them for promotions, or bring them along as their assistants when they got promoted." (Salami, 2010). In light of the above discussion, it is necessary to understand that behavioral integrity is necessary for effective mentoring.

It is evident that the leaders become more responsible for their actions and employees' actions in behavioral integrity. If the employees are going to be mentored appropriately, then the organization will progress. Social learning theory explains that employees learn from their leaders and mentors, and in this way, the organization will achieve success. In previous studies, the mediating role of political mentoring is not much known between the association of ethical leadership and behavioral integrity. So the following hypothesis is postulated based on this logical statement:

H4: Political mentoring mediates the association between ethical leadership and behavioral integrity.

The Mediating Role of Political Mentoring between Ethical Climate and Ethical Leadership

Mentoring in the organization means that a senior person must perform the guidance and advisory services to grow his protégés' careers (Siegel et al., 2011). Viator and Pasewark (2005) exhibited that mentoring is well defined as a developing cycle, including separation, redefinition refinement, and initiation to support more junior staff (Lim et al., 2015). Eby et al. 
(2006), using social learning theory and social information-processing theory, claimed that the managers perform as the information filters and powerful referents due to their hold in the punishments and reinforcement (Bandura, 1977; $\underline{\text { Salancik }}$ \& Pfeffer, 1978). This will help to create an excellent ethical climate in the organization. Schneider and Rentsch (1988) defined the ethical climate as the entities operationalize routine actions and behaviors that are supported, rewarded, and expected. Victor and Cullen (1988) further defined the ethical climate as predicting an explanation of ethical behavior. Pagliaro et al. (2018) also explained it as different from the other climates as "the prevailing perception of typical organizational practices and procedures that have ethical content" (Victor \& Cullen, 1988).

A recent study described that ethical leadership has a significant effect on ethical climate and subsequently on subordinates' ethical behavior (Lu \& Lin, 2013). Specifically, this study revealed that subordinates show enhanced ethical behavior since ethical leaders support ethical guidance. They lead and manage ethical conduct in the workplace. Furthermore, ethical leaders develop an ethical climate, which, in turn, positively affects the ethical behavior of subordinates. The findings of their study are consistent with previous studies expressing that business leaders use various techniques to convey ethical guidelines to their followers on different levels, which have an impact on followers' behavior (Mayer et al., 2009). It has an important influence on an organizational ethical climate in turn ( $\mathrm{Lu} \& \mathrm{Lin}, 2013)$. The organizational ethical climate is created and sustained through the leader's actions and initiatives (Wimbush et al., 1997). However, this research was done in a particular Asian cultural background where power distance might significantly impact the consequences of the leader's influence on subordinates' perceptions related to ethical climate and consequently subordinates' behaviors. Henceforth, it can be summarized that such results may differ in an organization that functions in Western cultural background, like Australia.

Nonetheless, the extent of research conducted on ethical climate depicts that limited research has been conducted on the association between ethical climate and ethical leadership (Shin, 2012). Based on the above discourse and following a call for future research, it is probable that ethical leadership influences the subordinates' perception of ethical climate in a respectful way. These findings indicate strong authentication that ethical leadership helps in establishing an ethical climate within an organization. Although the study conducted by Neubert et al. (2009) exhibits prominent strengths like a time gap and a large sample, and the researchers showed that the sample size was limited demographically.

From the above discussion, it is evident that the employees learn from their mentors and leaders in the organization as per social learning theory. If the employees are going to be appropriately mentored, then the organization will succeed. In the previous studies, the mediating role of political mentoring is still an under-investigated area between the relationship of ethical leadership and ethical climate. So based on these logical arguments, it is hypothesized that:

H5: Political mentoring mediates the association between ethical climate and ethical leadership.

\section{RESEARCH DESIGN AND METHODOLOGY}

\section{Participants and Procedure}

This study is considered quantitative research, which is applied to analyze the impact of behavioral integrity and ethical climate on the ethical leadership in an organization through the mediating role of political mentoring in Pakistan's service sector. In this study, the positivist paradigm approach was used to find the relationship among the variables of the study, and a well-designed questionnaire was utilized for the data gathering and analysis process. The basic aim of this approach is to organize problems, build hypotheses, check and summarize data to give a law-like and generalizable conclusion. The quantitative approach was used in this study because it develops the precision of results through statistical analysis and subjectivity components connected to the qualitative approach. Furthermore, in quantitative research, the researcher is independent, value-free and unbiased, structured and accurate, and reliable through reliability and validity testing. (Park \& Park, 2016). Furthermore, Barnham (2010) expressed that quantitative research is usually simpler to examine than qualitative research analysis since it reveals the correlations and regressions between two variables, and it gives concrete and factual data.

To reduce the common method bias, the questionnaire consists of two parts: the first one includes questions about the independent variables (behavioral integrity and ethical climate), and the second one includes the mediator (political mentoring) and dependent variable (ethical leadership). In this study, the non-probability sampling technique was used. It is a technique that does not follow the probability theory while selecting the appropriate sample. The sample was collected from the different service sectors such as health care centers, banks, insurance companies, education sectors, telecommunications, transportations, and hotel industries. In Social Science and Business fields, the structural equation modeling (SEM) technique is mostly used. This technique is useful to test the different theories and make them useable for the research question. SEM is classified into two types, covariance and variance-based SEM (Reinartz et al., 2009). In variance-based SEM, the researchers make proxies as linear combinations of observed variables and then use these proxies to estimate model parameters. In covariance-based SEM, empirical variance is used to estimate the parameters. The data 
collected through a survey questionnaire was analyzed using ADANCO 2.2 software for variance-based structural equation modeling. This software uses several information estimators such as Ordinary Least Square (OLS) Regression Analysis based on the sum of scores for analyzing and hypothesizing models and partial least squares path modeling (Henseler, 2017). In ADANCO software, correlation and confidence in the hypotheses are also analyzed, but it does not impose on the normality of data.

\section{Measures}

\section{Ethical Leadership}

Ethical leadership is determined by using a 10-item scale of Brown et al. (2005), which is the most commonly used scale to measure ethical leadership in management to operationalize the definition. Sample items include "My leader discusses business ethics or values with employees" and "My leader makes fair and balanced decisions." A 5-point Likert scale was used to measure the items that range from 1(strongly disagree) to 5 (strongly agree). Cronbach's Alpha of the scale was 0.89 .

\section{Ethical Climate}

The ethical climate is determined by using the scale of Victor and Cullen (1988), which is the most commonly used scale to measure this item. Sample items are "What is best for everyone is a major consideration here" and "In this company, the first consideration is whether a decision violates any law." A 5-point Likert scale was applied, ranging from 1 (strongly disagree) to 5 (strongly agree), to measure the items. Cronbach's Alpha of the scale was 0.86 .

\section{Behavioral Integrity}

The behavioral integrity is measured by the scale of Simons et al. (2007), which is the most widely used scale to measure this item. Sample items are "There is a match between my manager's words and actions" and "My manager conducts himself/herself by the same values he/she talks about." Items were measured on a 5-point Likert scale that ranges from "1 (strongly disagree) to 5 (strongly agree)." Cronbach's Alpha of the scale was 0.95 .

\section{Perceived Political Climate}

The perceived political climate is measured by the scale given by Neubert et al. (2009), which is the most widely used scale to measure this item. Sample items are "My mentor has demonstrated well-listening skills in our conversations" and "My mentor has shared personal experiences as an alternative perspective to my problems." A 5-point Likert scale ranging from 1 (strongly disagree) to 5 (strongly agree) was used to measure the items. Cronbach's Alpha of this scale was 0.95.

\section{Political Mentoring}

The items related to political mentoring were developed based on psychosocial and career functions identified by descriptive studies of mentoring associations and previously conducted qualitative analyses (e.g., Roche, 1979; Burke, 1984; Zey, 1984; Kram \& Isabella, 1985). These are the most widely used scales to measure this item. Sample items are "I sympathized with my manager/leader about the added problems that my request caused" and "I acted in a friendly manner with him/her before asking for what I wanted." A 5-point Likert scale was applied to measure items ranging from 1 (strongly disagree) to 5 (strongly agree). Cronbach's Alpha of the scale was 0.92

\section{Conceptual Framework}

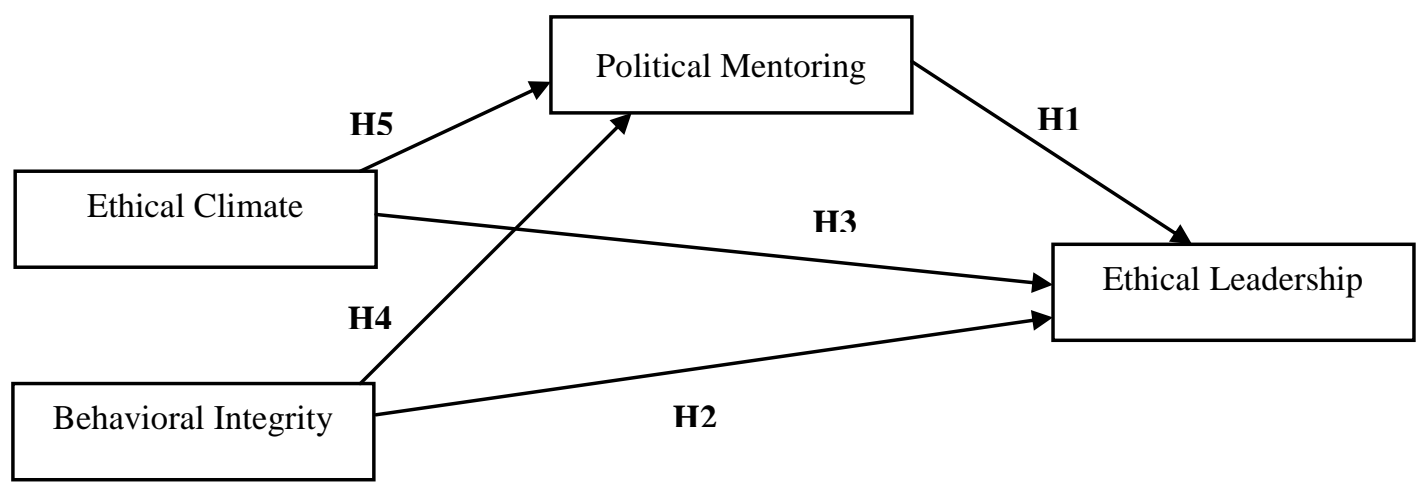

Figure 1: Conceptual Framework

Source: Author Analysis 


\section{Data Analysis}

The data gathered through a survey questionnaire was analyzed using ADANCO 2.2 software for variance-based structural equation modeling. This software uses several information estimators such as OLS regression analysis based on the sum of scores for analyzing and hypothesizing models and partial least squares path modeling (Henseler, 2017). In ADANCO software, correlation and confidence in the hypothesis are also analyzed, but it does not impose on the data normality. In this software, the first step is modeling the structural model and then calculating its validity and reliability.

The information about the demographic analysis is gathered through a questionnaire and is shown in Table 1. In this study, data were gathered from the different service sectors of Pakistan, and the frequencies of demographical aspects like gender, designation, experience, and type of organization were calculated through SPSS. In this study, data were gathered from 450 respondents. The majority of the respondents were male (54.2\%), the majority of the participants were having experience of $6-10$ years $(58.9 \%)$, most of the respondents were associated with the education sector $(20.7 \%)$, and the designation of the majority of the respondents was high-level (41.3\%).

\section{Demographic Profile of the Respondents}

Table 1: Demographic Profile of the Respondents

\begin{tabular}{|c|c|c|c|}
\hline Characteristics & Classification & Frequency & $\begin{array}{l}\text { Percentage } \\
(\%)\end{array}$ \\
\hline \multirow[t]{3}{*}{ Gender } & Male & 244 & 54.2 \\
\hline & Female & 206 & 45.8 \\
\hline & Total & 450 & 100 \\
\hline \multirow[t]{4}{*}{ Experience } & $1-5$ years & 74 & 16.4 \\
\hline & 6-10 years & 265 & 58.9 \\
\hline & More than 10 years & 111 & 24.7 \\
\hline & Total & 450 & 100 \\
\hline \multirow[t]{8}{*}{ Organization } & $\begin{array}{l}\text { Health-care } \\
\text { (Hospitals) }\end{array}$ & 76 & 16.9 \\
\hline & All Banks & 36 & 8 \\
\hline & Education sector & 93 & 20.7 \\
\hline & $\begin{array}{l}\text { Insurance } \\
\text { companies }\end{array}$ & 48 & 10.7 \\
\hline & Hotel industry & 82 & 18.2 \\
\hline & Telecommunication & 42 & 9.3 \\
\hline & $\begin{array}{l}\text { Transportation } \\
\text { services }\end{array}$ & 73 & 16.2 \\
\hline & Total & 450 & 100 \\
\hline \multirow[t]{4}{*}{ Designation } & Low level & 86 & 19.1 \\
\hline & Middle level & 178 & 39.6 \\
\hline & High level & 186 & 41.3 \\
\hline & Total & 450 & 100 \\
\hline
\end{tabular}

\section{Structural Model}

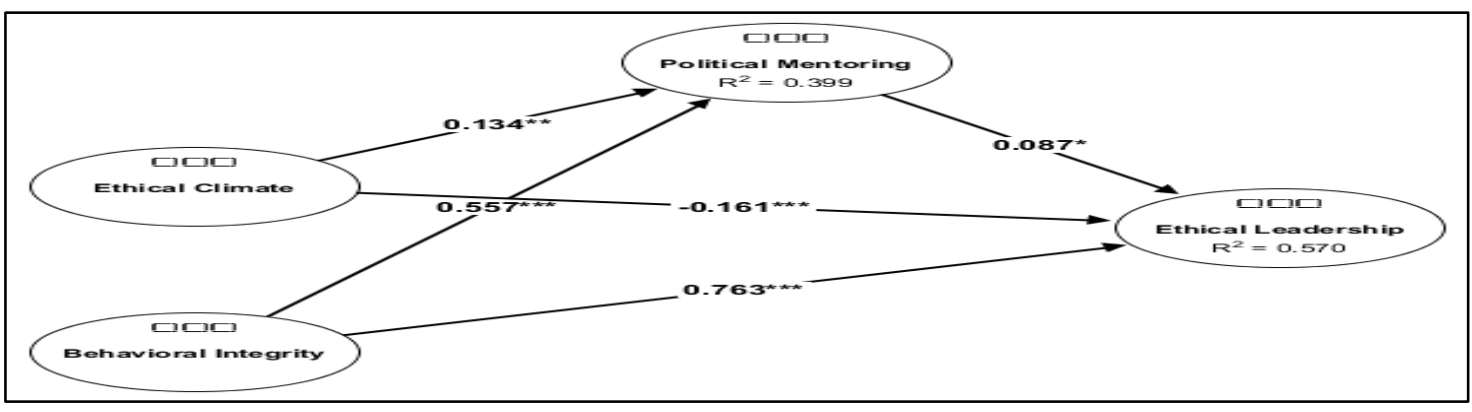

Figure 2: Structural Model 
Source: Author Analysis

Reliability of the Constructs and Convergent Validity

Table 2: Reliability of the Constructs and Convergent Validity

\begin{tabular}{lllll}
\hline Constructs & $\boldsymbol{R}^{\mathbf{2}}$ & Jöreskog's Rho $(\boldsymbol{\rho c})$ & Cronbach's Alpha $(\boldsymbol{\alpha})$ & AVE \\
\hline Political Mentoring & 0.3985 & 0.9059 & 0.7939 & 0.8280 \\
\hline Behavioral Integrity & 0.9521 & 0.9247 & 0.8689 \\
\hline Ethical Climate & 0.8683 & 0.6996 & 0.7675 \\
\hline Ethical Leadership & 0.9215 & 0.8309 & 0.8545 \\
\hline
\end{tabular}

The reliability of the model is determined through Cronbach's Alpha (Henseler et al., 2009). The alpha value threshold is 0.70 , and the above is considered a satisfactory level of reliability. To observe the model uniformity and consistency, Joreskog's Rho value is used (Henseler et al., 2009). The threshold for the Joreskog's Rho is 0.70 or above. In Table 2, all Joreskog's Rho values are above 0.80, which ensures high reliability. Convergent validity (CV) is defined as the point at which two theoretically related constructs should be related (Campbell \& Fiske, 1959). The minimum threshold for the average variance extracted (AVE) is 0.50 . All the values of AVE are greater than 0.50, which confirms the convergent validity.

\section{Discriminant Validity: Fornell-Larcker's Criteria}

Table 3: Discriminant Validity: Fornell-Larcker’s Criteria

\begin{tabular}{lllll}
\hline Constructs & Political Mentoring & Behavioral Integrity & Ethical Climate & Ethical Leadership \\
\hline Political Mentoring & $\mathbf{0 . 8 2 8 0}$ & & & \\
\hline Behavioral Integrity & 0.3847 & $\mathbf{0 . 8 6 8 9}$ & & \\
\hline Ethical Climate & 0.1582 & 0.2251 & $\mathbf{0 . 7 6 5 6}$ & \\
\hline Ethical Leadership & 0.2461 & 0.5484 & 0.0555 & $\mathbf{0 . 8 5 4 5}$ \\
\hline
\end{tabular}

Discriminant validity means whether the concepts that should not be related are unrelated or not. For this purpose, the researcher used Fornell-Larcker's criteria (Cable et al., 2014). As per this criteria, the square root of AVE should be greater than the correlation values of other constructs. It is clear from Table 3 that all the AVE values are greater than the correlational values of constructs. So, discriminant validity is satisfactory in this model.

\section{Results of Hypotheses Testing}

ADANCO 2.2 is variance-based software. It can also be used to test the hypotheses. To model the unknown population of the data, the option of bootstrapping was used (Sarstedt et al., 2011). T-statistics are used to measure the level of significance.

Table 4: Results of Hypotheses Testing

\begin{tabular}{lllllllll}
\hline & Hypotheses & \multicolumn{7}{c}{ Standard Bootstrap Result } \\
\cline { 2 - 9 } & & Coefficient & Mean & $\begin{array}{l}\text { Standard } \\
\text { Error }\end{array}$ & $\begin{array}{l}\text { p-value (2- } \\
\text { t-value } \\
\text { sided) }\end{array}$ & $\begin{array}{l}\text { p-value } \\
\text { (1-sided) }\end{array}$ & Status \\
\hline H1 & PM->EL & 0.0868 & 0.0862 & 0.0441 & 1.9698 & 0.0491 & 0.0246 & Accepted \\
\hline H2 & BI -> EL & 0.5569 & 0.5586 & 0.0491 & 11.3450 & 0.0000 & 0.0000 & Accepted \\
\hline H3 & EC -> EL & 0.1493 & 0.1481 & 0.0329 & 4.5727 & 0.0000 & 0.0000 & Accepted \\
\hline H4 & BI ->PM-> EL & 0.0484 & 0.0482 & 0.0253 & 1.9146 & 0.0055 & 0.0279 & Accepted \\
\hline H5 & EC-> PM->EL & 0.0116 & 0.0114 & 0.0074 & 1.5668 & 0.1175 & 0.0500 & Rejected \\
\hline
\end{tabular}

Note: $\mathrm{PM}=$ Political mentoring, $\mathrm{EL}=$ Ethical leadership, $\mathrm{BI}=$ Behavioral integrity, $\mathrm{EC}=$ Ethical climate

\section{DISCUSSION}

$\mathrm{H} 1$ shows the positive influence of political mentoring on ethical leadership. The t-value is 1.9698 , and the p-value is 0.0491 , which is significant at a 5\% significance level. Thus $\mathrm{H} 1$ is accepted. Previous research described that a direct relationship exists between political mentoring and ethical leadership (Dashper, 2020). In this study, positive t-value verifies that good political mentoring determines the leader's role to build strong ethics under his leadership.

$\mathrm{H} 2$ shows the positive impact of behavioral integrity on ethical leadership. The t-value is 11.3450 , and the p-value is 0.0000 , which is significant at a $1 \%$ significance level. Thus $\mathrm{H} 2$ is accepted. Prior studies estimated the positive relationship between behavioral integrity and ethical leadership (Chan, 2020). In this study, the positively related t-values clearly show that if the 
employees have integrity in their actions, they take the mentoring sessions seriously to make the organization and their personality traits better.

$\mathrm{H} 3$ shows the impact of the ethical climate on ethical leadership. The t-value is 4.5727 , and the p-value is 0.0000 , which is significant at a $1 \%$ significance level. Thus $\mathrm{H} 3$ is accepted. Previous research found the association between ethical leadership and ethical climate (Kim et al., 2015). In this study, the positive t-value verifies that the leaders create an ethical environment for the employees and this ethical climate leads towards organizational success.

H4 shows the mediating role of political mentoring between the relationship of behavioral integrity and ethical leadership. The t-value is 1.9146 , and the p-value is 0.0055 , significant at a $1 \%$ significance level. Thus $\mathrm{H} 4$ is supported. Previous studies like Berson et al. (2015) also investigated the mediating role of political mentoring between behavioral integrity and ethical leadership. In this study, mediation is present between the variables, which testifies that behavioral integrity impacts ethical leadership in the presence of mentoring.

H5 shows the mediating role of political mentoring between the ethical climate and ethical leadership. The t-value is 1.5668, and the p-value is $0.1175>0.05$, which shows no mediation in this relationship. Thus H5 is not accepted. Earlier studies like Carroll et al. (2020) found the association between ethical leadership and ethical climate. The reason is that it is not necessarily true that if the climate is progressive, then the leaders perform well. It all depends on how they perceive the organizational climate and how they deliver to them. The leaders' political mentoring is not necessary for the good ethical climate of the organization.

\section{CONCLUSION}

Leaders are the essential pillars for the success of the organization and for the development of ethical behavior (Kouzes \& Posner, 2017). This study examined the mediating role of political mentoring in an organizational ethical climate, behavioral integrity, and ethical leadership. The mentor's role is to give an employee guidance about an organizational environment and working conditions. Politically, the mentor's role is to make sure that guidance given to the employee about the environment is appropriate and consistent with the organizational norms and policies. The fundamental objective of this study is to check the role of ethical leadership in the organization with proper mentoring. So, the environment of the organization becomes constructive and supportive for the employees. If the manager plays his part in the organization rightly, the organizational environment becomes more comfortable. In this way, the progress of the organization will increase. This study clearly shows the strong mediating effect of political mentoring among the ethical leader, behavioral integrity, and ethical climate.

The results indicate that the mediating role of political mentoring between the relationship of ethical climate and ethical leadership is not supportive, as discussed earlier ( $\mathrm{Lu} \& \mathrm{Lin}, 2013$ ). But the mediation of political mentoring between the association of behavioral integrity and ethical leadership is vital (Jones, 2019). These results clearly show that the leader should be a man of principle and ethically vital for organizational success. It means that the leader's role matters in building the organizational employees' character and success. The climate never makes a leader (Simha \& Cullen, 2012). It is the leader who makes the climate of the organization through his integrity and actions.

This study has several strengths. First, the population is taken from the service industry, and face-to-face interaction was made to reduce the mistakes in the data collection. In addition, this study contributes to business ethics as the role of political mentoring in the ethical climate is unknown (Lim et al., 2015). This study helps to conceptualize the mediating part of political mentoring in an organizational climate. In conclusion, this research examines how mentors play their part in building the employees' character so they can perform well in the organization. It also manifests the leader's role in building a supportive and collaborative environment for employees to work diligently and adequately.

\section{LIMITATIONS AND STUDY FORWARD}

Besides all this, there are some limitations to this study. The sample is mainly collected from Pakistan's service sector, so the data is not demographically diverse. The researchers can conduct research by gathering data from the service sectors of other countries. Moreover, the data is collected from one province of Pakistan; therefore, it cannot be generalized to Pakistan's overall service sector. The researchers can increase the generalizability of the results in the future by collecting data from other provinces. Other than the variables used in this study, future research can be conducted by adding the different variables and analyzing the moderating role of political mentoring. In addition, the data in this study were collected at one point in time. Therefore, future researchers can gather the data at multiple points in time to observe the causal associations. Finally, this study was quantitative, and future researchers can adopt a qualitative approach in the future.

\section{ACKNOWLEDGEMENT}

First, we would like to thank Allah Almighty for giving us the strength to complete this research. Then we would like to appreciate the efforts of the faculty of the Institute of Business Administration (IBA) and Hailey College of Commerce 
(HCC) for encouraging us to conduct this research. In last, we want to thank all the academicians who helped us to carry out this study.

\section{CO-AUTHORS' CONTRIBUTION}

All the authors in this article have declared no conflict of interest. All the authors have contributed to complete this article. Waqas Baig has carried out the data analysis and conceptualization. Rizwan Qaiser Danish has contributed to data collection and validation. Muqqadas Rehman has written the original draft and has worked on project administration. Muhammad Hasnain has contributed to methodology, final review, and editing. Hafiz Fawad Ali has a contribution related to the interpretation of concepts.

\section{REFERENCES}

1. Avolio, B. J., \& Gardner, W. L. (2005). Authentic leadership development: Getting to the root of positive forms of leadership. The Leadership Quarterly, 16(3), 315-338. https://doi.org/10.1016/j.leaqua.2005.03.001

2. Bandura, A. (1977). Social learning theory. Prentice-hall.

3. Bandura, A. (1986). Fearful expectations and avoidant actions as coeffects of perceived self-inefficacy. https://psycnet.apa.org/doi/10.1037/0003-066X.41.12.1389

4. Barnham, C. (2010). Qualis? The qualitative understanding of essence. International Journal of Market Research, 52(6), 757-773. https://doi.org/10.2501/S1470785310201648

5. Beadle-Brown, J., Bigby, C., \& Bould, E. (2015). Observing practice leadership in intellectual and developmental disability services. Journal of Intellectual Disability Research, 59(12), 1081-1093. https://doi.org/10.1111/j ir.12208

6. Berson, Y., Da'as, R. A., \& Waldman, D. A. (2015). How do leaders and their teams bring about organizational learning and outcomes? Personnel Psychology, 68(1), 79-108. https://doi.org/10.1111/peps.12071

7. Blass, F. R., \& Ferris, G. R. (2007). Leader reputation: The role of mentoring, political skill, contextual learning, and adaptation. Human Resource Management, 46(1), 5-19. https://doi.org/10.1002/hrm.20142

8. Brown, M. E., Trevino, L. K., \& Harrison, D. A. (2005). Ethical leadership: A social learning perspective for construct development and testing. Organizational Behavior and Human Decision Processes, 97(2), 117-134. https://doi.org/10.1016/j.obhdp.2005.03.002

9. Burke, R. J. (1984). Mentors in organizations. Group \& Organization Management, 9(3), 353-372.

10. Burlew, L. D. (1991). Multiple mentor model: A conceptual framework. Journal of Career Development, 17(3), 213-221 https://doi.org/10.1177\%2F089484539101700306

11. Cable, D. M., Cable, D. M., Derue, D. S. (2014). The convergent and discriminant validity of subjective fit perceptions. Journal of Applied Psychology, 87(5), 875-884. https://doi.org/10.1037/0021-9010.87.5.875

12. Campbell, D. T., \& Fiske, D. W. (1959). Convergent and discriminant validation by the multitrait-multimethod matrix. Psychological Bulletin, 56(2), 81. https://psycnet.apa.org/doi/10.1037/h0046016

13. Carroll, A. B., Adler, N. J., Mintzberg, H., Cooren, F., Suddaby, R., Freeman, R. E., \& Laasch, O. (2020). What is responsible management? A conceptual potluck. In Research Handbook of Responsible Management. Edward Elgar Publishing. https://doi.org/10.4337/9781788971966

14. Chan, S. C. (2020). Transformational leadership, self-efficacy, and performance of volunteers in non-formal voluntary service education. Journal of Management Development. https://doi.org/10.1108/JMD-03-2020-0078

15. Charles, O. (2016). Improving trust through ethical leadership: moving beyond the social learning theory to a historical learning approach. Journal of Media Critiques, 2(8). https://doi.org/10.17349/jmc116201

16. Chong, J. Y., Ching, A. H., Renganathan, Y., Lim, W. Q., Toh, Y. P., Mason, S., \& Krishna, L. K. (2020). Enhancing mentoring experiences through e-mentoring: a systematic scoping review of e-mentoring programs between 2000 and 2017. Advances in Health Sciences Education, 25(1), 195-226. https://doi.org/10.1007/s10459019-09883-8

17. Danish, R. Q., Ahmed, A., Farooq, S., Baig, W., \& Ahmed-Ullah, H. (2021). Ethics and Politics: What determines Ethical ledership under Political Mentoring? Academic Journal of Social Sciences, 4(4), 1-15.

18. Dashper, K. (2020). Mentoring for gender equality: Supporting female leaders in the hospitality industry. International Journal of Hospitality Management, 88, 102397. https://doi.org/10.1016/j.ijhm .2019 .102397

19. Dickson, G., Van Aerde, J., \& Tholl, B. (2020). Pathway to professionalizing health leadership in Canada: the two faces of Janus. Healthcare Management Forum, 33(1), 25-29. Sage, CA: Los Angeles, CA: SAGE Publications. https://doi.org/10.1177\%2F0840470419869035

20. Eby, L. T., Lockwood, A. L., \& Butts, M. (2006). Perceived support for mentoring: A multiple perspectives approach. Journal of Vocational Behavior, 68(2), 267-291. https://doi.org/10.1016/j.jvb.2005.07.003 
21. Elci, M., \& Alpkan, L. (2009). The impact of perceived organizational ethical climate on work satisfaction. Journal of Business Ethics, 84(3), 297-311. https://doi.org/10.1007/s10551-008-9709-0

22. Engelbrecht, A. S., Heine, G., \& Mahembe, B. (2017). Integrity, ethical leadership, trust, and work engagement. Leadership \& Organization Development Journal. https://doi.org/10.1108/LODJ-11-2015-0237

23. Feldman, D. C., \& Weitz, B. A. (1991). From the invisible hand to the gladhand: Understanding a careerist orientation to work. Human Resource Management, 30(2), 237-257. https://doi.org/10.1002/hrm.3930300206

24. Haring, M. J. (1999). The case for a conceptual base for minority mentoring programs. Peabody Journal of Education, 74(2), 5-14. https://doi.org/10.1207/s15327930pje7402_2

25. Henseler, J. (2017). ADANCO 2.0. 1-User manual. Kleve: Composite Modeling GmbH \& Co. https://s01b5a2c23b2a9902.jimcontent.com/download/version/1497806399/module/14443507124/name/ADANC O\%202.0.1\%20User\%20Manual.pdf

26. Henseler, J., Ringle, C. M., \& Sinkovics, R. R. (2009). The use of partial least squares path modeling in international marketing. New challenges to international marketing. Emerald Group Publishing Limited. https://doi.org/10.1007/s10551-013-1868-y

27. Jones, J. A. (2019). Implementing Behavioral Integrity: Understanding Ethical and Moral Leadership. Academy of Management Proceedings, 13408. https://doi.org/10.5465/AMBPP.2019.13408abstract

28. Kernis, M. H., \& Goldman, B. M. (2006). A multicomponent conceptualization of authenticity: Theory and research. Advances in Experimental Social Psychology, 38, 283-357. https://doi.org/10.1016/S00652601(06)38006-9

29. Kim, M. Y., Miao, Q., \& Park, S. M. (2015). Exploring the relationship between ethical climate and behavioral outcomes in the Chinese Public Sector: The mediating roles of affective and cognitive responses. International Journal of Business, Humanities, and Technology, 5(3), 88-103. https://doi.org/10.1007/s11846-019-00340-9

30. Kochan, F., Searby, L., George, M. P., \& Edge, J. M. (2015). Cultural influences in mentoring endeavors: Applying the cultural framework analysis process. International Journal of Mentoring and Coaching in Education. https://doi.org/10.1108/IJMCE-03-2015-0010

31. Kouzes, J. M., \& Posner, B. Z. (2017). The leadership challenge workbook. John Wiley \& Sons.

32. Kozlowski, S. W., \& Doherty, M. L. (1989). Integration of climate and leadership: Examination of a neglected issue. Journal of applied psychology, 74(4), 546. https://psycnet.apa.org/doi/10.1037/0021-9010.74.4.546

33. Kram, K. E., \& Isabella, L. A. (1985). Mentoring alternatives: The role of peer relationships in career development. Academy of Management Journal, 28(1), 110-132. https://doi.org/10.2307/256064

34. Lakey, C. E., Kernis, M. H., Heppner, W. L., \& Lance, C. E. (2008). Individual differences in authenticity and mindfulness as predictors of verbal defensiveness. Journal of Research in Personality, 42(1), 230-238. https://doi.org/10.1016/j.jrp.2007.05.002

35. Leroy, H., Anseel, F., Gardner, W. L., \& Sels, L. (2015). Authentic leadership, authentic followership, basic need satisfaction, and work role performance: A cross-level study. Journal of Management, 41(6), 1677-1697. https://doi.org/10.1177\%2F0149206312457822

36. Leroy, H., Palanski, M. E., \& Simons, T. (2011). Authentic Leadership and Behavioral Integrity as Drivers of Follower Commitment and Performance: JBE. Journal of Business Ethics, 107(3), 255-264. https://doi.org/10.1 007/s10551-011-1036-1

37. Lim, L., Clarke, A., Ross, F., \& Wells, J. (2015). Mentoring experiences, perceived benefits, and impact on current job positions of African American accountants. Advancing Women in Leadership Journal, 35, 193-203. https://doi.org/10.18738/awl.v35i0.135

38. Loftus, E. F., Miller, D. G., \& Burns, H. J. (1978). Semantic integration of verbal information into a visual memory. Journal of experimental psychology: Human learning and memory, 4(1), 19. https://psycnet.apa.org/do $\mathrm{i} / 10.1037 / 0278-7393.4 .1 .19$

39. Lu, C. S., \& Lin, C. C. (2013). The effects of ethical leadership and ethical climate on employee

40. Mayer, D. M., Kuenzi, M., Greenbaum, R. L., Bardes, M., \& Salvador, R. (2009). How low does ethical leadership flow? Test of a trickle-down model. Organizational Behavior and Human Decision Processes, 108(1), 1-13. https://doi.org/10.1016/J.OBHDP.2008.04.002

41. Miao, C., Humphrey, R. H., \& Qian, S. (2018). Emotional intelligence and authentic leadership: a metaanalysis. Leadership \& Organization Development Journal. https://doi.org/10.1108/LODJ-02-2018-0066

42. Mo, S., \& Shi, J. (2017). Linking ethical leadership to employee burnout, workplace deviance, and performance: Testing the mediating roles of trust in leader and surface acting. Journal of Business Ethics, 144(2), 293-303. https://doi.org/10.1007/s10551-015-2821-z

43. Neubert, M. J. (2019). With or without spirit: Implications for scholarship and leadership. Academy of Management Perspectives, 33(3), 253-263. https://doi.org/10.5465/amp.2016.0172 
44. Neubert, M. J., Carlson, D. S, Kacmar, K. M., Roberts, J. A., \& Chonko, L. B. (2009). The virtuous influence of ethical leadership behavior: Evidence from the field. Journal of Business Ethics, 90(2), 157-170. https://doi.org/10.1007/s10551-009-0037-9

45. Pagliaro, S., Lo Presti, A., Barattucci, M., \& Giannella, V. A., \& Barreto, M. (2018). On the Effects of Ethical Climate(s) on Employees' Behavior: A Social Identity Approach. Frontiers in Psychology, 9, 960. https://doi.org/10.3389/fpsyg.2018.00960

46. Palanski, M. E., \& Yammarino, F. J. (2007). Integrity and leadership: clearing the conceptual confusion. European Management Journal, 25(3), 171-184. https://doi.org/10.15577/jmt.2016.03.01.1

47. Park, J., \& Park, M. (2016). Qualitative versus quantitative research methods: Discovery or justification? Journal of Marketing Thought, 3(10), 1-7. https://doi.org/10.1016/j.emj.2007.04.006

48. Prottas, D. J. (2013). Relationships among employee perception of their manager's behavioral integrity, moral distress, and employee attitudes and well-being. Journal of Business Ethics, 113(1), 51-60. https://doi.org/10 $.1007 / \mathrm{s} 10551-012-1280-\mathrm{Z}$

49. Qin, X., Huang, M., Hu, Q., Schminke, M., \& Ju, D. (2018). Ethical leadership, but toward whom? How moral identity congruence shapes the ethical treatment of employees. Human Relations, 71(8), 1120-1149. https://doi.org/10.1177\%2F0018726717734905

50. Reinartz, W., Haenlein, M., \& Henseler, J. (2009). An empirical comparison of the efficacy of covariance-based and variance-based SEM. International Journal of Research in Marketing, 26(4), 332-344. https://doi.org/1 0.1016/j.ijresmar.2009.08.001

51. Roche, G. R. (1979). Much ado about mentors. Harvard Business Review, 57, 14-28.

52. Saha, R., Cerchione, R., Singh, R., \& Dahiya, R. (2020). Effect of ethical leadership and corporate social responsibility on firm performance: A systematic review. Corporate Social Responsibility and Environmental Management, 27(2), 409-429. https://doi.org/10.1002/csr.1824

53. Salami, S. O. (2010). Career plateauing and work attitudes: Moderating effects of mentoring others with Nigerian employees. Europe's Journal of Psychology, 6(4), 71-92. https://doi.org/10.5964/ejop.v6i4.224

54. Salancik, G. R., \& Pfeffer, J. (1978). A social information processing approach to job attitudes and task design. Administrative science quarterly, 224-253. https://www.jstor.org/stable/2392563, doi10.2307/2392563

55. Sarstedt, M., Henseler, J., \& Ringle, C. M. (2011). Multigroup analysis in partial least squares (PLS) path modeling: Alternative methods and empirical results. Measurement and research methods in international marketing. Emerald Group Publishing Limited. https://doi.org/10.1108/S1474-7979(2011)0000022012

56. Schminke, M., Ambrose, M. L., \& Neubaum, D. O. (2005). The effect of leader moral development on ethical climate and employee attitudes. Organizational behavior and human decision processes, 97(2), 135-151. https://doi.org/10.1016/j.obhdp.2005.03.006

57. Schneider, B., \& Rentsch, J. (1988). Managing climates and cultures: A futures perspective.

58. Shin, Y. (2012). CEO ethical leadership, ethical climate, climate strength, and collective organizational citizenship behavior. Journal of Business Ethics, 108(3), 299-312. https://doi.org/ 10.1007/s10551-011-1091-7

59. Siegel, P. H., Schultz, T., \& Landy, S. (2011). Formal versus informal mentoring of MAS professionals. Journal of Applied Business Research (JABR), 27(2). https://doi.org/10.19030/jabr.v27i2.4135

60. Silvester, J., \& Menges, C. (2011). The political mentoring toolkit. http://openaccess.city.ac.uk/444/

61. Simha, A., \& Cullen, J. B. (2012). Ethical climates and their effects on organizational outcomes: Implications from the past and prophecies for the future. Academy of Management Perspectives, 26(4), 20-34. https://doi.org/10.5465/amp.2011.0156

62. Simons, T. (2002). Behavioral Integrity: The perceived alignment between managers' words and deeds as a research focus. Organization Science, 13(1), 18-35. https://doi.org/10.1287/orsc.13.1.18.543

63. Simons, T., Friedman, R., Liu, L. A., \& Parks, M. J. (2007). Racial differences in sensitivity to behavioral Integrity: Attitudinal consequences, in-group effects, and trickle-down among Black and non-Black employees. Journal of Applied Psychology, 92(3), 650. https://psycnet.apa.org/doi/10.1037/0021-9010.92.3.650

64. Thatcher, J. B., \& Perrewé, P. L. (2002). An empirical examination of individual traits as antecedents to computer anxiety and computer self-efficacy. MIS Quarterly, 381-396. https://www.jstor.org/stable/413 2314,doi10.2307/4132314

65. Trevino, L. K., Hartman, L. P., \& Brown, M. (2000). Moral person and moral manager: How executives develop a reputation for ethical leadership. California Management Review, 42(4), 128-142. https://doi.org/10.230 $7 \% 2 \mathrm{~F} 41166057$

66. Van-Gils, S., Van-Quaquebeke, N., Van-Knippenberg, D., Van-Dijke, M., \& De Cremer, D. (2015). Ethical leadership and follower organizational deviance: The moderating role of follower moral attentiveness. The Leadership Quarterly, 26(2), 190-203. https://doi.org/10.1016/j.leaqua.2014.08.005 
67. Viator, R. E., \& Pasewark, W. R. (2005). Mentorship separation tension in the accounting profession: The consequences of delayed structural separation. Accounting, Organizations, and Society, 30(4), 371-387. https://doi.org/10.1016/j.aos.2004.03.003

68. Victor, B., \& Cullen, J. B. (1988). The organizational bases of ethical work climates. Administrative science quarterly, 101-125. https://www.jstor.org/stable/2392857//doi.10.2307/2392857

69. Wang, D., Feng, T., \& Lawton, A. (2017). Linking ethical leadership with firm performance: a multi-dimensional perspective. Journal of Business Ethics, 145(1), 95-109. https://doi.org/10.1007/s10551-015-2905-9

70. Wilson, J. A., \& Elman, N. S. (1990). Organizational benefits of mentoring. Academy of Management Perspectives, 4(4), 88-94. https://doi.org/10.5465/ame.1990.4277215

71. Wimbush, J. C., Shepard, J. M., \& Markham, S. E. (1997). An empirical examination of the relationship between ethical climate and ethical behavior from multiple levels of analysis. Journal of Business Ethics, 16(16), 17051716.

72. Young, A. M., \& Perrewé, P. L. (2000). The exchange relationship between mentors and protégés: The development of a framework. Human Resource Management Review, 10(2), 177-209. https://doi.org/10.10 16/S1053-4822(99)00045-5

73. Zaim, H., Demir, A., \& Budur, T. (2020). Ethical leadership, effectiveness and team performance: an Islamic perspective. Middle East Journal of Management, 1(8). https://doi.org/10.1504/MEJM.2021.111991

74. Zey, M. G. (1984). The mentor connection. Homewood, IL: Dow-Jones-Irwin. 